\title{
INNOVATION: FINANCING
}

\section{AND FINANCING CONSTRAINTS}

B. Planes ${ }^{\mathrm{a}}$, M. Bardos ${ }^{\mathrm{a}}$, P. Sevestre ${ }^{\mathrm{b}}$ and S. Avouyi-Dovi ${ }^{\mathrm{b}}$

September 2001

${ }^{1}$ The authors are extremely grateful to Marc-Olivier Strauss-Kahn and Christian Pfister for their comments.

Of course, the views expressed here are those of the authors and do not necessarily reflect the views of the Banque de France. 


\section{INTRODUCTION}

Innovation is commonly considered to be an important factor in economic activity. At the micro level, it impacts corporate performances (Crépon and Iung (1999)) and has a bearing on the survival of firms, especially start-ups (Gharbi and Pradel (2001)). At the macro level, it has a strong influence on economic growth, and consequently also affects employment.

The acceleration of innovation in the last 10 years has thrown the question of financing innovation into even sharper relief. In France, several recent papers have been devoted to this issue, including Sauvé (1999), Guillaume (1998), and a report by SESSI ${ }^{2}$ (1998). However, financing theory is still mainly based on Williamson's article (1988), which concludes, inter alia, that innovation is principally funded by firms' own financing.

An examination of the ways in which innovation is financed is complicated by the fact that all the necessary data are not fully available. In France, three successive innovation surveys have been carried out, but none touches on sources of financing ${ }^{3}$. Only one survey, whose findings have not yet been released, has been devoted specifically to the financing of innovation. This makes it difficult to corroborate new theoretical ideas on financing.

Furthermore, few empirical studies on the issue of innovation financing have been devoted to a detailed investigation of the data produced in the most recent surveys. The main objective of this empirical study is, then, to identify the specific features of innovative companies in terms of financing, risk and access to credit. It also seeks to analyse specifically innovation financing by companies in the information and communication technologies (ICT) industries. However, start-ups are excluded from the scope of this study, because they were not covered by the innovation survey from which we are drawing our data ${ }^{4}$.

To achieve these objectives, this paper analyses the data from the most recent survey, conducted by SESSI for the manufacturing industry and by INSEE ${ }^{5}$ for services. These data are supplemented with accounting and financial information from the Central Balance Sheet Office (CBSO) ${ }^{6}$ of the Banque de France. Measures of company risk were obtained from the Banque de France's legal incidents database.

The paper proceeds as follows. Section 2 describes some stylised facts, including some general characteristics of innovative companies. Section 3, a crucial point of the analysis, considers the financing structure of innovative and non-innovative companies as well as the conditions governing access to financing for these companies, taking into account various criteria, such as economic and financial constraints. Section 4 aims to shed light on the financing issues affecting companies in the ICT industries. We then assess whether the results obtained for companies in other industries hold true overall or whether they show significant differences.

\footnotetext{
2 Department of Industrial Research and Statistics, under the authority of the Secretary of State for Industry

3 These surveys were conducted by the Ministry for the Economy, Finances and Industry, with SESSI surveying industry and INSEE surveying services. The first survey was conducted in 1990 and examined corporate approaches to innovation over the period 1986-1990. The second was conducted in 1993 and covered the period 1990-1992. The third was carried out in 1997 and looked at corporate approaches to innovation.

${ }^{4}$ For further reading on this topic, see the study carried out by the Companies Division of the Banque de France.

${ }^{5}$ French National Statistical Institute

${ }^{6}$ Centrale de Bilans
} 


\section{STYLISED FACTS}

According to the 1997 Community Innovation Survey (CIS), a company is deemed to be innovative if it has at least partially developed and/or marketed an innovative production process or product during the period 1994-1996 (see Appendix 1 for a description of the CIS). These two types of innovation are not easily separated, because the release of new products may entail the implementation of new manufacturing processes. Consequently, we do not distinguish between them in this study. The period covered by the survey is relatively noteworthy since, for companies, it corresponds to a macroeconomic situation characterised overall by extensive debt retrenchment by businesses, together with relative stability in borrowing costs (see Appendix 2). The period under review also predates France's Innovation Act, adopted in January 1999, as well as the creation of the Nouveau Marché in November $1996^{7}$.

Appendices 1 briefly discusses the main characteristics of the databases used in this study, as well as the coverage ratio by size and industry of the CBSO database in comparison with the sample used in the SESSI survey.

\subsection{The propensity to innovate is related to size and industry}

The statistics in this section were obtained using a breakdown by size (in term of payroll) and by industry, based on all companies in the INSEE database which exactly correspond to the studied population (i.e. companies with over 20 employees and which are subject to the specific French BICBRN tax regime).

On the basis of the above definition, almost half (44.6\%) the companies employing more than 20 people in the broad manufacturing industries - which exclude agri-food and energy but include business-related services such as transport, communication, real estate, renting and business activities - reported technological innovations over the period of the survey (1994-1996). These companies employed $69.1 \%$ of the total workforce of the industries surveyed and produced around three-quarters of their total output ( $74.6 \%$ of turnover and $73.9 \%$ of value added).

Computing the contribution of innovative companies to the total turnover of different categories of firms defined according to their turnover, we see that the larger the companies, the higher the contribution (see Graph 1). In the category of companies reporting a turnover of less than FRF 50 million (in 1997 francs), which covers $68.6 \%$ of all companies, the innovative firms contribute just over $40 \%$ to the total turnover of this size during the period under review. Conversely, in the category of companies reporting a turnover of over FRF 250 million (about 8\% of companies in the industry), almost $90 \%$ of the total turnover can be attributed to innovative companies. Company size therefore seems to be a determining factor in innovation.

\footnotetext{
${ }^{7}$ Data from the latest survey, which covers a more recent period, are not yet available. When they are, it will be possible to add to the comments and conclusions arising from the first survey.
} 


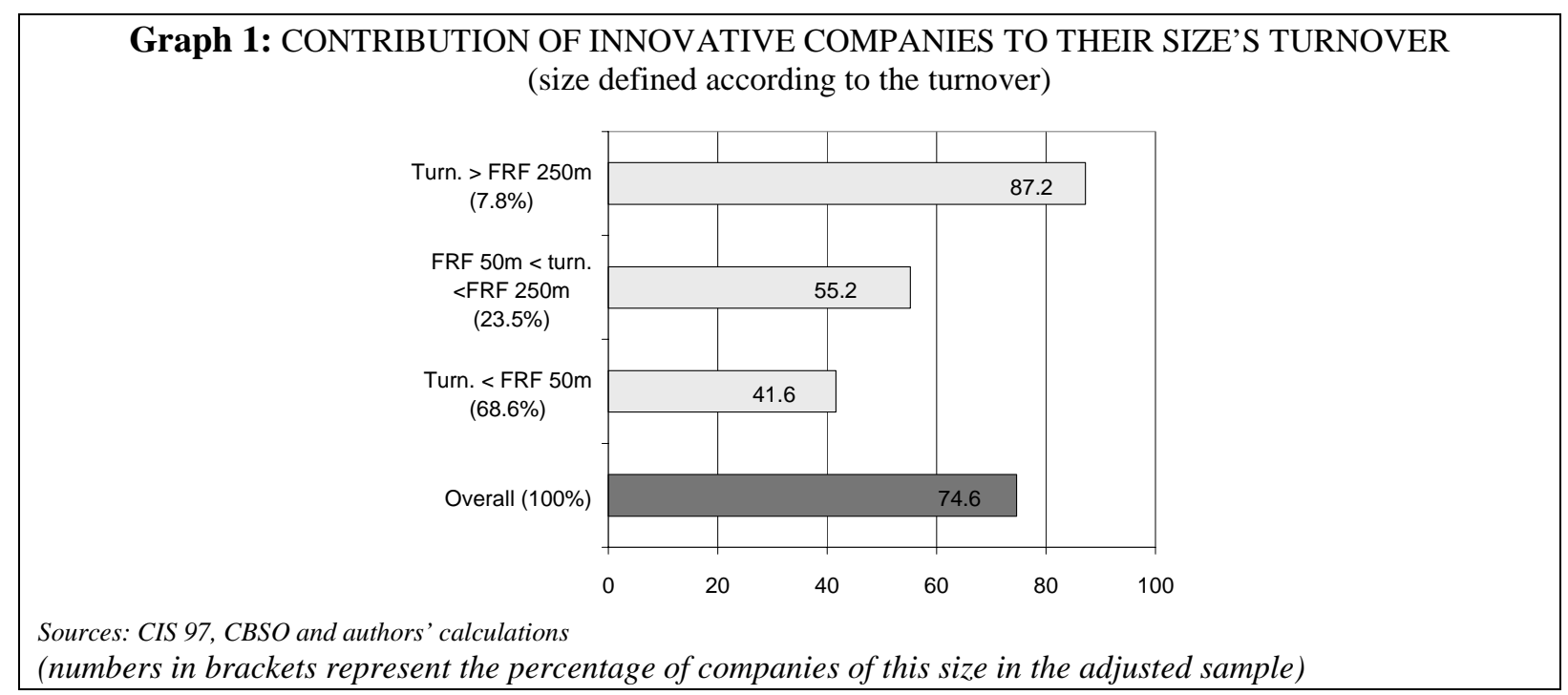

An examination of the contributions of innovative firms to the turnover in their respective industries reveals wide sector-based differences (see Graph 2), with contributions ranging from around $36 \%$ in the "Mining and quarrying except energy producing materials" industry, to over $90 \%$ in the "Manufacturing of transport equipment" industry. Generally speaking, innovative companies in the high-tech industries (manufacture of transport equipment, electrical and electronic equipment, machinery and equipment, and chemical industry) make the largest contributions to their industry turnover.

Transport and telecommunications services, which are grouped together under the NACE classification system, seem to be among the weakest in terms of innovation, with innovative companies contributing just over $40 \%$ to the industry turnover. This is due to an aggregation effect ${ }^{8}$, but also reflects the fact that this category comprises services that do not, a priori, necessitate major technological innovations, unlike equipment manufacturing. Accordingly, industries involved in equipment manufacturing top the rankings.

\footnotetext{
${ }^{8}$ For the telecommunications only, the contribution of innovative companies to the industry's turnover is around $66 \%$.
} 
Graph 2 : CONTRIBUTION OF INNOVATIVE COMPANIES TO THEIR INDUSTRY'S TURNOVER

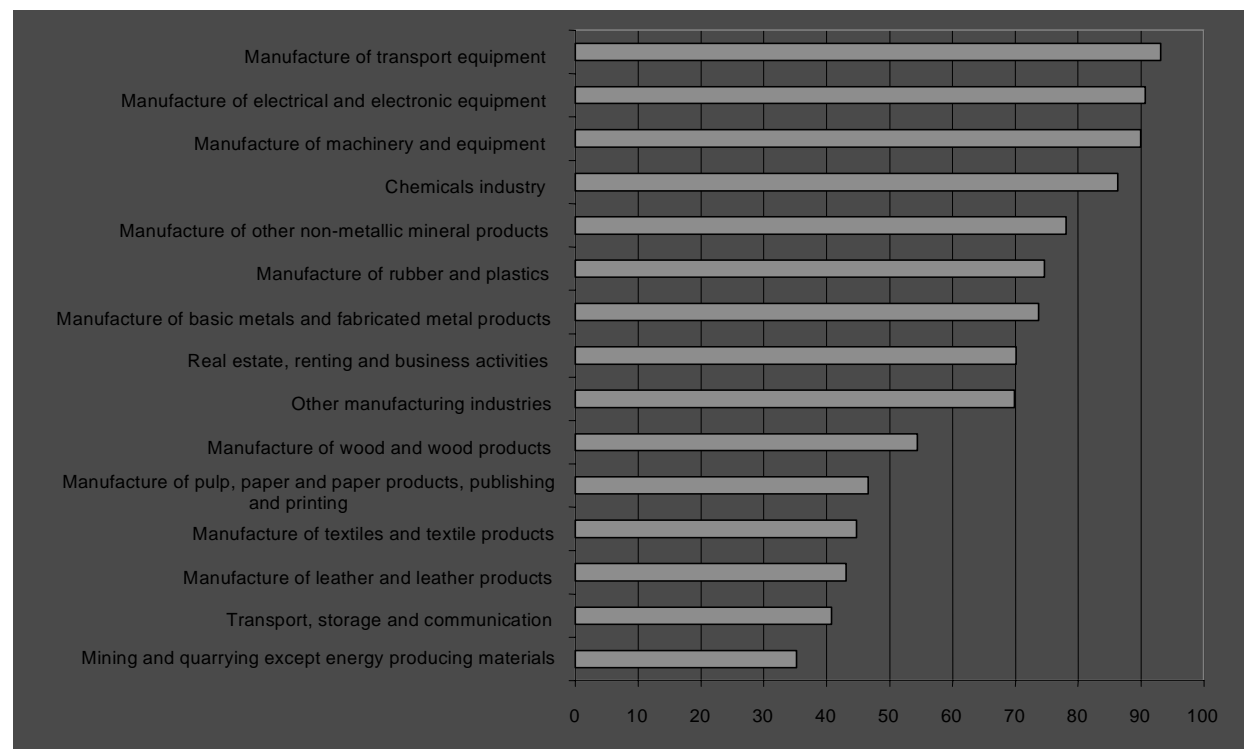

Sources: CIS 97, CBSO and authors' calculations

\subsection{Innovative firms invest more in intangible assets}

Working on the premise that innovative companies have invested, it may prove useful to examine their investment. For this, we use the investment ratio, i.e. total gross investment ${ }^{9}$ divided by value added, as an indicator. As expected, this ratio is, on average over the period 1994-96, significantly higher among innovative companies (21.4\%) than among non-innovative companies $(17.8 \%)$. This result is obtained, controlling for size and industry, using the methodology presented in Appendix 3. Innovative companies also have a higher research and development (R\&D) investment ratio ${ }^{10}(3.1 \%)$ than non-innovative companies $(2.4 \%)$. These results reflect a key characteristic of innovative companies, i.e. that they have to lay the groundwork for innovations before actually carrying them out. The same differences emerge in the period preceding the one under review (199293): future innovative companies invested more than non-innovative companies not only during, but also prior to the period in which they claimed to have innovated ${ }^{11}$.

Breaking down gross investment into tangible investment, intangible investment and financial investment over the survey period and over the preceding period, we find that (Graph 3) ${ }^{12}$ :

- Intangible investment was proportionately higher among innovative companies than among non-innovative ones. During the period under review, this type of investment took on even more importance, especially for innovative companies, which continued to "lead" non-innovative firms, allocating $9.7 \%$ of their total investment to intangible investment, compared with $8.0 \%$ for noninnovative companies. In addition, the increase in the proportion allocated to intangible investment by innovative companies almost completely offset the $1.3 \%$ decline in the proportion allotted to tangible investment. In terms of the difference in GFCF, financial and intangible investments accounted for around $20 \%$ of the investment of innovative companies, compared with $16 \%$ for non-innovative companies.

\footnotetext{
${ }^{9}$ Tangible, intangible and financial investment

${ }^{10}$ (R\&D investment booked on the balance sheet + R\&D costs booked under charges) / Value added in current francs

11 The CIS does not allow us to find out whether the innovative firm over the 1994-96 period was also previously innovative. Duguet and Monjon (2001), however, emphasised the persistence of innovations.

${ }^{12}$ Investment excluding increases in charges to be spread over several periods
} 
- The proportion of financial investment was relatively stable over the two periods. However, innovative companies allocated a greater proportion (10\%) of total investment to financial investment, compared with $8 \%$ for non-innovative companies.

- Tangible investment naturally accounted for the lion's share of investment by innovative and non-innovative companies alike in both periods. That said, tangible investment occupied a larger portion of total investment among non-innovative companies, accounting for $84.4 \%$ between 1992 1993 and $83.4 \%$ between 1994-1996, whereas for innovative companies, it represented $81.4 \%$ of total investment over 1992-1993 and 80.1\% between 1994-1996. Between the two periods, the proportion accorded to tangible investment fell slightly, particularly among innovative companies.

These structural differences do not mean that non-innovative companies make a more tangible investment effort than innovative companies. Indeed, the tangible investment/value-added ratio amounted to $14.9 \%$ for innovative companies compared with $12.9 \%$ for non-innovative companies. The same applied to intangible investment and financial investment, which accounted for respectively $2 \%$ and $1.4 \%$ among innovative companies, compared with $2.3 \%$ and $0.7 \%$ among non-innovative companies. However, between the two periods, the tangible investment/value added ratio for innovative companies decreased from $16.1 \%$ to $14.9 \%$.

\section{Graph 3 : BREAKDOWN OF TOTAL GROSS INVESTMENT BY TYPE AND BY PERIOD (controlling for size and industry)}

$1992-93$

$1994-96$

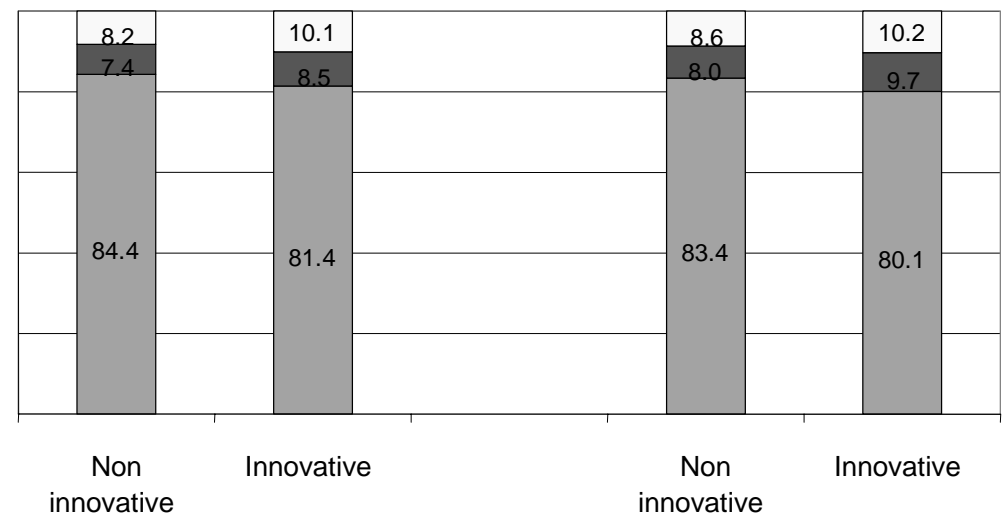

$\square$ Tangible investment $\quad \square$ Intangible investment

$\square$ Financial investment

Sources: CIS 97, CBSO and authors' calculations

\subsection{Innovation does not seem strongly related to income, profitability and failure rates}

Controlling for size and industry, an analysis of income and profitability indicators (profit margin, return on equity, apparent productivity of labour, cash flow, rate of value added) does not, overall, reveal any meaningful differences between the two categories of company, either in the period preceding the survey (1992-1993) or during the survey period (1994-1996).

A sector-based analysis of the same indicators broadly confirms these conclusions, while introducing an additional nuance. In manufacturing industries (excluding agri-food and energy), the income indicators are either identical or slightly more favourable to innovative companies, with the exception of the "Manufacture of pulp, paper and paper products, publishing and printing" industry.

Those indicators are only clearly favourable to innovative companies in the "Real estate, renting and business activities" industry, where the profit margin of innovative companies is $9.6 \%$, 
compared with $5.3 \%$ for non-innovative companies, and the rate of value added is $53.2 \%$, compared with $46.5 \%$.

An ex post analysis of failure rates ${ }^{13}$ supplies results that are consistent with those for the income and profitability indicators. Again, delivers no meaningful difference between innovative and non-innovative companies with respect to risk, controlling for size and industry can be detected. The average failure rate among innovative companies is $4.5 \%$, compared with $4.2 \%$ for non-innovative ones. Here, the results from the different sub-industries offer no additional insights. However, failure rates are significantly higher $(6.1 \%$ versus $3.3 \%)$ in less innovative industries (i.e. where innovative firms make a contribution of less than 50\% to the industry's turnover) than in those industries where innovative firms make a larger contribution ${ }^{14}$.

The score recorded by the BDFI ${ }^{15}$, the composite indicator of corporate soundness in industry calculated by the Banque de France's Companies Observatory, confirms this diagnosis and shows no material difference in the soundness of innovative companies and non-innovative companies, at either the overall or industry level.

\subsection{Nevertheless, innovation is often obstructed or abandoned due to financing obstacles}

The CIS survey allows us to identify the various constraints or obstacles affecting innovation projects (see Table 1). Taking into account all constraints (i.e. economic, organisational, legal and market-related), 56.2\% of businesses surveyed (adjusted sample) declared that they had delayed, abandoned or not started an innovation project. This percentage rises to $71.8 \%$ among innovative companies, and falls to $43.9 \%$ for non-innovative companies.

Table 1 : PERCENTAGE OF FIRMS HAVING DELAYED, ABANDONED OR NOT STARTED A PROJECT, BY TYPE OF OBSTACLE ENCOUNTERED (adjusted sample)

\begin{tabular}{|c|c|c|c|c|}
\hline Obstacle & & $\begin{array}{c}\text { Non- } \\
\text { innovative } \\
\end{array}$ & Innovative & Overall \\
\hline Economic & Financial + profitability & 37.0 & 53.9 & 44.4 \\
\hline \multirow[t]{2}{*}{ Financial } & $\begin{array}{l}\text { Innovation costs too high } \\
\text { Lack of appropriate sources of finance }\end{array}$ & 30.8 & 42.7 & 36.1 \\
\hline & o/w lack of appropriate sources of finance & 20.2 & 24.4 & 22.0 \\
\hline Profitability & Economic risks perceived to be excessive & 29.3 & 38.1 & 33.2 \\
\hline Organisational & $\begin{array}{l}\text { Organisational rigidities } \\
\text { Lack of qualified personnel } \\
\text { Lack of information on technology } \\
\text { Lack of information on markets }\end{array}$ & 24.8 & 44.7 & 33.6 \\
\hline Legal & $\begin{array}{l}\text { Legislation, regulations, norms, } \\
\text { standards }\end{array}$ & 19.0 & 16.6 & 17.9 \\
\hline Market-related & Lack of customer responsiveness to new products & 20.2 & 25.7 & 22.6 \\
\hline Total & & 43.9 & 71.8 & 56.2 \\
\hline
\end{tabular}

Sources: CIS 97, CBSO and authors' calculations

A detailed analysis of the different types of obstacle shows that economic obstacles, such as high costs, excessive economic risk and a lack of appropriate sources of finance, as well as organisational constraints, hamper or even adversely impact innovation projects for innovative and

\footnotetext{
${ }^{13}$ The failure rate: the number of failed companies over the period 1997-2000 divided by the number of companies monitored.

14 The industry groupings are defined according to the degree of innovation (see graph 2). The thresholds used to distinguish between low, average and highly innovative groups are $60 \%$ and $80 \%$ of the industry-based turnover.

${ }^{15}$ The BDFI score is a composite indicator of company risk. It consists of a linear combination of ratios symptomatic of risk, including the profitability, solvency, debt and income ratios.
} 
non-innovative companies alike. However, the proportion of companies subject to these constraints is significantly higher among innovative companies. This is not surprising considering that constraints on innovation projects affect firms which seek to innovate.

Actual financial constraints (i.e. a lack of appropriate sources of finance) concern around onequarter $(24.4 \%)$ of innovative companies, compared with $20.2 \%$ in the case of non-innovative companies. In addition of the $22 \%$ of all companies that experienced financing constraints, $7.9 \%$ delayed their project, and $10.4 \%$ never even began it. These difficulties affect a smaller proportion of large firms $(16.3 \%)$ than medium-sized $(21.4 \%)$ or small enterprises $(22.8 \%)$. They also vary considerably from industry to industry (see Appendix 4): in general, industries where innovative companies make the highest contribution to turnover are more seriously affected by financial constraints.

The proportion of innovative companies facing market-related constraints was barely greater than the proportion of non-innovative companies (26\% versus around $20 \%$ ).

A great many firms thus claimed to have faced financial obstacles that hampered their innovation projects. More than one-third of companies with an innovation project claim that they experienced financing difficulties, and $16.4 \%$ of those firms wishing to innovate had to abandon the project because of these difficulties.

The following section will verify the existence of these financing constraints and attempt to explain their nature, firstly by examining the specific features of financing for innovative companies, secondly by conducting a similar study of companies facing constraints.

\section{IS FINANCING AFFECTED BY WHETHER A COMPANY IS INNOVATIVE OR NOT?}

\subsection{Innovative firms get a high fraction of the available finance, but they might suffer from bank credit constraints}

At a macro-economic level, graphs 4 and 5 allow us to compare, for the period 1994-1996, the contribution of innovative companies to total turnover and the breakdown of different types of financing between innovative and non-innovative companies. Looking at the main components of financing (own financing, outside-group financial debt, intra-group financing, cyclic borrowings), we see that innovative firms have a share of each type of financing roughly equal to or slightly greater than their share of turnover (see Graph 4). In the industries under review, around $81 \%$ of own financing is absorbed by innovative firms, which generate $74.6 \%$ of total turnover. Proportions are similar for intra-group financing $(82.2 \%)$.

The proportion of outside-group financial debt, however, is slightly lower in comparison, at $74.6 \%$. If we separate outside-group financial debt into its main components, we see that the proportion of bank loans absorbed by innovative firms (64\%) is not in line with their effective contribution to the total turnover (see Graph 5). This indicates either that the banking industry is relatively adverse to risky loans or that innovative firms are adverse to this type of financing, 

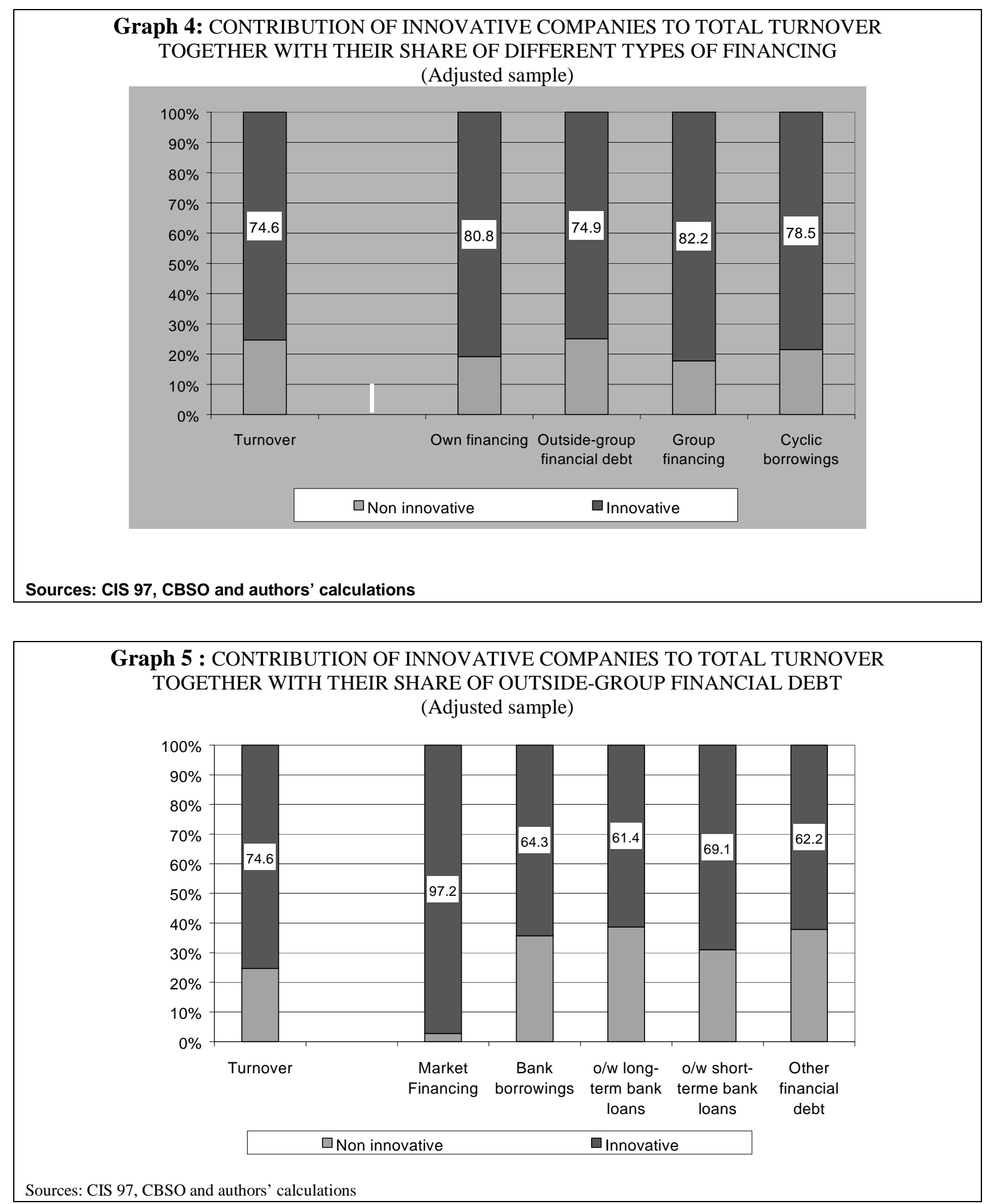

\subsection{Slight differences in financing structures}

Graphs 4 and 5, which represent the macroeconomic level, provide no indications as to the financing structure of companies. For this, we calculated average balance sheet structures for innovative and non-innovative companies, controlling for size and industry effects, using the methodology described in Appendix 3. Moreover, given that innovative firms invest more, we took the investment ratio into account when computing the following statistics. In this way, we can measure the 
differences linked principally to innovation and not those linked to investment. Table 2 sets out the balance sheet structures of the two types of companies. The ratios are averages calculated for the period preceding the survey and for the survey period.

Table 2 - BALANCE SHEET STRUCTURE: AVERAGE RATIOS (TAKING INTO ACCOUNT SIZE, INDUSTRY AND INVESTMENT RATIO)

\begin{tabular}{|l|rr|rr|}
\hline \multirow{2}{*}{ Own financing } & \multicolumn{2}{|c|}{$1992-93$} & \multicolumn{2}{c|}{$1994-96$} \\
\cline { 2 - 6 } \multicolumn{1}{|c|}{ Non inno. } & Inno. & Non inno. & Inno. \\
Investment subsidies & $\mathbf{5 2 . 2}$ & $\mathbf{5 3 . 8}$ & $\mathbf{5 3 . 6}$ & $\mathbf{5 5 . 1}$ \\
Outside-group financial debt & 0.2 & 0.3 & 0.1 & 0.2 \\
Market financing & $\mathbf{1 5 . 6}$ & $\mathbf{1 5 . 9}$ & $\mathbf{1 3 . 5}$ & $\mathbf{1 3 . 6}$ \\
Bank borrowings & 0.2 & 0.4 & 0.2 & 0.3 \\
long-term bank loans & 14.2 & 13.6 & 12.1 & 11.6 \\
short-term bank loans & 8.4 & 7.7 & 6.5 & 6.3 \\
Other financial debt & 5.8 & 5.9 & 5.6 & 5.3 \\
Intra-group financing & 1.2 & 1.9 & 1.2 & 1.7 \\
Cyclic borrowings & $\mathbf{6 . 4}$ & $\mathbf{5 . 8}$ & $\mathbf{6 . 0}$ & $\mathbf{5 . 9}$ \\
\hline Balance sheet total & $\mathbf{2 5 . 9}$ & $\mathbf{2 4 . 5}$ & $\mathbf{2 6 . 9}$ & $\mathbf{2 5 . 4}$ \\
\hline
\end{tabular}

Sources: CIS 97, CBSO and authors' calculations.

Two items - "own financing" and "cyclic borrowings " - can be used as discriminating factors when analysing the financing structure of the two categories.

Own financing is by far the biggest component of company debt, accounting for more than $52 \%$ of the total in both periods and for both categories. The proportion of this type of financing is significantly higher among innovative companies than among non-innovative ones. Furthermore, there was a slight increase in the weight of this type of financing during the period under review, reflecting the debt retrenchment by companies at that time.

Cyclic borrowings, which comprise a fairly broad range of non-financial debt, including tax and social-security debt, commercial debt and other non-financial debt, are proportionately the second most important type of financing for companies, accounting for around one-quarter of the financing of both categories of company ${ }^{16}$. Non-innovative companies appear to accord greater weight to this item (26.9\%, compared with $25.4 \%$ for innovative companies over the period under review). The share of this type of borrowing increased by 100 basis points over 1994-1996. Interestingly, there was a marked decline in outside-group financial debt; notably, bank borrowing, the main component of this type of debt, fell by roughly the same amount in both categories.

These results might seem to indicate that recourse to the different types of financing is more or less uniform. Table 3 refines our initial remarks concerning the financing structure of companies by indicating the percentage of firms that actually used these different types of financial debt. There do not appear to be any material differences between the two categories in terms of bank borrowing, especially long-term loans, as well in terms of intra-group financing. However, use of short-term bank loans increased in the period covered by the survey.

\footnotetext{
${ }^{16}$ The weight of "Cyclic borrowings" should be put in perspective, however. Commercial debt, which accounts for approximately one-half of the item, is offset by trade receivables worth a similar amount. These borrowings do not have the same status as financial debt insofar as they are mainly short-term. They are not suitable for more long-term expenditures of the type required for innovation. Increased recourse to this type of debt is often a sign of financial frailty.
} 
Furthermore, innovative companies made more often use of market financing, a fact mainly explained by their size (see Appendix 5). Similarly, they are also more numerous to make use of "other financial debt".

Table 3: PERCENTAGE OF COMPANIES MAKING USE OF DIFFERENT TYPES OF FINANCING (ADJUSTED SAMPLE)

\begin{tabular}{|c|c|c|c|c|}
\hline & \multicolumn{2}{|c|}{$1992-93$} & \multicolumn{2}{|c|}{ 1994-96 } \\
\hline & $\begin{array}{l}\text { Non } \\
\text { inno. }\end{array}$ & Inno. & $\begin{array}{l}\text { Non } \\
\text { inno. }\end{array}$ & Inno. \\
\hline Market financing & 2.9 & 6.0 & 2.7 & 4.9 \\
\hline Bank borrowings & 96.7 & 98.1 & 97.1 & 98.3 \\
\hline Long-term bank loans & 92.8 & 92.4 & 91.4 & 89.2 \\
\hline Short-term bank loans & 82.2 & 87.4 & 84.7 & 90.9 \\
\hline Other financial debt & 40.3 & 57.4 & 42.7 & 57.0 \\
\hline Intra-group financing & 83.3 & 86.2 & 86.2 & 88.6 \\
\hline Total financial debt & 100.0 & 100.0 & 100.0 & 100.0 \\
\hline
\end{tabular}

Sources: CIS 97, CBSO and authors' calculations

It is also instructive to conduct a more specific analysis of financial debt (including intra-group financing), which accounts for around one-fifth of total financing for companies (see Table 4). The effects of bank debt retrenchment can be observed: the weight of bank borrowing goes slightly down for both categories. Furthermore, innovative companies make slightly but significantly less use of bank borrowing as a proportion of financial debt. Doubtless because specific types of financing, such as ANVAR funding ${ }^{17}$, exist for innovative companies, the weight of "other financial debt" is almost 300 basis points higher among innovative firms than among non-innovative companies in both periods. The share of intra-group financing rose over the period of the survey.

Table 4 : STRUCTURE OF FINANCIAL DEBT

\begin{tabular}{|l|cc|cc|}
\hline & \multicolumn{2}{|c|}{$1992-93$} & \multicolumn{2}{c|}{$1994-96$} \\
& Non inno. & Inno. & Non inno. & Inno. \\
\hline Market & $\mathbf{1 . 0}$ & $\mathbf{1 . 4}$ & $\mathbf{1 . 0}$ & $\mathbf{1 . 3}$ \\
\multicolumn{1}{|c}{ Song-term bank debt } & $\mathbf{6 3 . 6}$ & $\mathbf{6 0 . 8}$ & $\mathbf{6 0 . 9}$ & $\mathbf{5 8 . 1}$ \\
Short-term bank debt & 40.8 & 37.8 & 36.2 & 34.0 \\
Other financial debt & 22.8 & 23.0 & 24.8 & 24.1 \\
Intra-group financing & $\mathbf{7 . 4}$ & $\mathbf{1 0 . 7}$ & $\mathbf{7 . 8}$ & $\mathbf{1 0 . 1}$ \\
\hline Total & $\mathbf{2 8 . 0}$ & $\mathbf{2 7 . 0}$ & $\mathbf{3 0 . 3}$ & $\mathbf{3 0 . 5}$ \\
\hline
\end{tabular}

Sources: CIS 97, CBSO and authors' calculations

\footnotetext{
${ }^{17}$ ANVAR, the Agence nationale de valorisation de la recherche, provides interest-free funding to assist innovation projects, up to a maximum of $50 \%$ of expenditure, refundable only if the project is a success. Assistance is also provided for innovation-related recruitment.
} 


\subsection{Innovative firms pay lower interest rates on their debt}

Overall, taking into account the size, industry, investment level and short-term to long-term debt ratio ${ }^{18}$, a significant difference emerges between the average calculated interest rates ${ }^{19}$ on external financing for the two categories of companies over the survey period (see Table 5).

Table 5: CALCULATED INTEREST RATES ${ }^{20}$ FOR INNOVATIVE AND NON-INNOVATIVE FIRMS

\begin{tabular}{|l|c|c|}
\hline & Non-innovative & Innovative \\
\hline $\begin{array}{l}\text { Calculated interest rate on outside-group financial } \\
\text { debt, excluding guaranteed obligations }\end{array}$ & 11.8 & 10.7 \\
Calculated interest rate on intra-group financing & 3.4 & 3.2 \\
\hline Calculated interest rate on external financing ${ }^{21}$ & 8.9 & 8.1 \\
\hline
\end{tabular}

Sources: CIS 97, CBSO and authors' calculations

It appears that when companies market innovations they see their borrowing costs falls. This may be due to the fact that, on the one hand, innovative companies have recourse to specific low-cost financing (or even zero-cost financing, such as ANVAR-type loans) and, on the other hand, they have a stronger balance sheet structure than non-innovative companies (they are less indebted) and can obtain more favourable loan conditions than non-innovative firms

Generally speaking, recourse to "other financial debt" naturally lowers the calculated interest rates ${ }^{22}$ : companies resorting to this type of financing obtain an average rate ${ }^{23}$ of $10.3 \%$ compared with $13.2 \%$ for those that do not. This differential (up to around 300 basis points) is favourable to innovative companies, which make more use of this form of debt.

However, the difference in calculated interest rates between innovative companies and noninnovative companies is not entirely due to their recourse to "other financial debt". Indeed, for the firms which do not have recourse to this type of financing, the calculated interest rate on outside-group financial debt remains much lower among innovative companies (see Table 6).

Table 6: CALCULATED INTEREST RATES

(Based on whether or not firms have recourse to other financial debt)

\begin{tabular}{|c|c|c|c|c|}
\hline & \multirow{2}{*}{\multicolumn{2}{|c|}{$\begin{array}{l}\text { Non-innovative } \\
\text { Recourse to other } \\
\text { financial debt }\end{array}$}} & \multirow{2}{*}{\multicolumn{2}{|c|}{$\begin{array}{c}\text { Innovative } \\
\text { Recourse to other } \\
\text { financial debt }\end{array}$}} \\
\hline & & & & \\
\hline & no & yes & no & yes \\
\hline $\begin{array}{l}\text { Calculated interest rate on outside-group financial } \\
\text { debt, excluding guaranteed obligations }\end{array}$ & 13.7 & 10.8 & 12.7 & 9.9 \\
\hline Calculated interest rate on intra-group financing & 3.3 & 3.4 & 2.8 & 3.3 \\
\hline Calculated interest rate on external financing & 9.7 & 8.4 & 8.7 & 7.8 \\
\hline
\end{tabular}

Sources: CIS 97, CBSO and authors' calculations

\footnotetext{
${ }^{18}$ Indeed, interest rates on short-term loans differ from those on long-term loans. We want to control for this composition effect.

19 These interest rates are calculated on the basis of available accounting data.

${ }^{20}$ Here, the estimated interest rates are much higher than the cost of bank loans over this particular period (see graph in Appendix 2) as they include a wider bracket of debt than simple bank loans. They take into account loans from other credit institutions, and leases. We do not have pure bank interest rates at our disposal.

${ }^{21}$ External financing includes all outside-group and intra-group financial debt.

${ }^{22}$ Rather, this is a form of long-term debt with interest rates lower than short-term debt.

${ }^{23}$ Calculated interest rate on outside-group financial debt, excluding guaranteed obligations.
} 
Furthermore, innovative companies in highly innovative industries are subject to a higher outside-group borrowing cost than other categories, but enjoy lower interest rates on intra-group financing (see Appendix 6)

\subsection{Financing constraints appear to be an important criterion for understanding companies' behaviour towards innovation}

Data from CIS 97 show which firms have experienced financing constraints for to their innovative projects. Thus, four categories of firm can be distinguished: those which have not attempted to innovate (or ended their innovation projects for other reasons than financing constraints), those which aborted their innovation projects as a result, at least partially, of financing constraints, those which innovated despite the presence of financing constraints, and those innovative firms which did not experience financing constraints.

For non-innovative companies, the presence of financial constraints only had a slight effect on their calculated interest rates on outside-group debt, i.e. a small difference of 20 basis points (see table 7) ${ }^{24}$. However, for innovative companies, the presence of financial constraints is clearly penalising, irrespective of the type of debt, with a 130-basis point difference in interest rates, naturally in favour of companies without financial constraints. Moreover, where constraints are present, innovation is not in the least advantageous for companies, as both categories are subject to the same rates.

However, it might be the case that these apparently paradoxical results for non-innovative firms, stem from the fact that non-innovative firms comprise both firms for which not to innovate was a choice (non constrained firms) and firms for which it was a forced decision (constrained firms).

Table 7: CALCULATED INTEREST RATES BETWEEN 1994-1996 FOR INNOVATIVE AND NON-INNOVATIVE FIRMS WHETHER THEY HAVE, OR HAVE NOT, BEEN SUBJECT TO FINANCIAL CONSTRAINTS

\begin{tabular}{|c|c|c|c|c|}
\hline & \multicolumn{2}{|c|}{ NON-INNOVATIVE } & \multicolumn{2}{|c|}{ INNOVATIVE } \\
\hline & $\begin{array}{l}\text { without } \\
\text { constraints }\end{array}$ & $\begin{array}{l}\text { with } \\
\text { constraints }\end{array}$ & $\begin{array}{l}\text { without } \\
\text { constraints }\end{array}$ & $\begin{array}{l}\text { with } \\
\text { constraints }\end{array}$ \\
\hline $\begin{array}{l}\text { Calculated interest rate on outside-group financial } \\
\text { debt, excluding guaranteed obligations }\end{array}$ & 11.9 & 11.7 & 10.4 & 11.7 \\
\hline Calculated interest rate on intra-group financing & 3.4 & 3.6 & 3.0 & 3.8 \\
\hline Calculated interest rate on external financing & 8.9 & 8.9 & 7.8 & 9.0 \\
\hline
\end{tabular}

Sources: CIS 97, CBSO and authors' calculations

Amongst the companies not subject to financial constraints, innovative firms enjoyed a more favourable cost of credit on external financing. This was not the case for companies with financial constraints ${ }^{25}$ : innovative and non-innovative have the same level of interest rate.

The difference between the calculated interest rates paid by innovative firms whether they face financial constraints or not may be explained by the greater recourse to intangible investment $(R \& D$

\footnotetext{
${ }^{24} \mathrm{NB}$ : financial constraint reflected by the calculated interest rate is skewed in that, on the one hand, financial constraint can be total or partial, and the loans observed in the balance sheet have been accepted by the company and the creditor. Consequently, their cost is probably lower than those that have not been accepted and that also reflect the financial constraint. On the other hand, financial constraint in the survey only refers to loans requested for innovative projects. Firms and, in particular, large companies have other non-innovative projects (less risky) financed by loans that may lower the overall borrowing cost observed.

25 However, in this study we are taking into account only financial constraints on innovation projects and not all financial constraints. Thus, companies may have financial constraints on other projects. This could explain why there is no significant difference between interest rates paid by non-innovative firms experiencing constraints and those paid by non-innovative firms not experiencing constraints.
} 
effort ${ }^{26}$ is $3 \%$ compared with $1.8 \%$ during the survey period, and $2.7 \%$ compared with $1.9 \%$ in 1992 1993). Consequently, there is less collateral available to the bank in terms of coverage in the event of bankruptcy. The loan (not necessarily the project) is therefore riskier.

However, this difference can also be explained by the financial position of companies. Not only are financially constrained companies' profit margins lower than those of firms without constraints (8.9\% versus $10.1 \%$ during the period $1992-1993$ and $8.2 \%$ versus $9.7 \%$ during the survey) but, more importantly, their balance sheet structure shows a higher debt ratio, which indicates greater financial fragility. Moreover, the proportion of short-term bank loans of innovative firms with constraints is significantly higher for these two periods, which increases the total proportion of bank borrowing in the balance sheet structure. A large reliance on cyclic borrowings is a sign of financial difficulty as it often reflects longer suppliers' deadlines and higher tax liability and social security debt.

Therefore, financial constraints experienced by innovative firms may (at least partially) be the result of a poor structure, or at least poorer than that of other companies, and not only due to a riskier project. The comparison with non-innovative firms with and without financial constraints (see Table 9) confirms these results.

Table 8: BALANCE SHEET STRUCTURE OF INNOVATIVE FIRMS STATING THAT THEY HAVE, OR HAVE NOT, BEEN SUBJECT TO FINANCIAL CONSTRAINTS.

\begin{tabular}{|c|c|c|c|c|}
\hline & \multicolumn{2}{|c|}{ 1992-1993 } & \multicolumn{2}{|c|}{ 1994-1996 } \\
\hline & $\begin{array}{c}\text { Without } \\
\text { constraints }\end{array}$ & $\begin{array}{c}\text { With } \\
\text { constraints }\end{array}$ & $\begin{array}{c}\text { Without } \\
\text { constraints }\end{array}$ & $\begin{array}{c}\text { With } \\
\text { constraints }\end{array}$ \\
\hline Own financing & 55.1 & 50.0 & 56.2 & 51.7 \\
\hline Investment subsidies & 0.3 & 0.2 & 0.3 & 0.2 \\
\hline Outside-group financial debt & 15.4 & 18.0 & 13.2 & 15.5 \\
\hline Market financing & 0.4 & 0.4 & 0.2 & 0.4 \\
\hline Bank borrowings & 13.2 & 15.9 & 11.4 & 13.6 \\
\hline long-term bank loans & 7.6 & 8.6 & 6.3 & 6.9 \\
\hline short-term bank loans & 5.6 & 7.3 & 5.1 & 6.7 \\
\hline Other financial debt & 1.9 & 1.6 & 1.6 & 1.5 \\
\hline Group financing & 5.6 & 5.1 & 5.7 & 5.3 \\
\hline Cyclic borrowings & 23.8 & 27.0 & 24.9 & 27.5 \\
\hline Total & 100 & 100 & 100 & 100 \\
\hline
\end{tabular}

Sources: CIS 97, CBSO and authors' calculations

\footnotetext{
${ }^{26} \mathrm{R} \& \mathrm{D}$ costs and expenditure in value added
} 
Table 9: BALANCE SHEET STRUCTURE OF NON-INNOVATIVE FIRMS STATING THAT THEY HAVE, OR HAVE NOT, BEEN SUBJECT TO FINANCIAL CONSTRAINTS

\begin{tabular}{|c|c|c|c|c|}
\hline & \multicolumn{2}{|c|}{ 1992-1993 } & \multicolumn{2}{|c|}{ 1994-1996 } \\
\hline & $\begin{array}{c}\text { Without } \\
\text { constraints }\end{array}$ & $\begin{array}{c}\text { With } \\
\text { constraints }\end{array}$ & $\begin{array}{c}\text { Without } \\
\text { constraints }\end{array}$ & $\begin{array}{c}\text { With } \\
\text { constraints }\end{array}$ \\
\hline Own financing & 51.2 & 49.3 & 52.6 & 50.9 \\
\hline Investment subsidies & 0.2 & 0.5 & 0.2 & 0.2 \\
\hline Outside-group financial debt & 16.0 & 16.8 & 13.8 & 15.4 \\
\hline Market financing & 0.2 & 0.1 & 0.2 & 0.2 \\
\hline Bank borrowings & 14.4 & 15.4 & 12.3 & 13.5 \\
\hline long-term bank loans & 8.4 & 9.2 & 6.7 & 6.7 \\
\hline short-term bank loans & 6.0 & 6.2 & 5.7 & 6.8 \\
\hline Other financial debt & 1.4 & 1.3 & 1.4 & 1.7 \\
\hline Group financing & 7.1 & 7.0 & 6.8 & 6.5 \\
\hline Cyclic borrowings & 25.8 & 26.9 & 26.8 & 27.2 \\
\hline Total & 100.0 & 100.0 & 100.0 & 100.0 \\
\hline
\end{tabular}

Sources: CIS 97, CBSO and authors' calculations

Non-innovative firms with financial constraints, i.e. firms which had an innovation project hampered (at least partially) by financial constraints, have the least favourable balance sheet structure of all companies, for the two periods. These firms did not manage to implement their innovation projects because their financial structure did not enable them to incur risk. During the survey period, their proportion of own financing was $50.9 \%$, compared with $51.7 \%$ for innovative firms with financial constraints, $52.6 \%$ for non-innovative without financial constraints and $56.2 \%$ for innovative firms without financial constraints.

Generally, innovative firms use a large proportion of own financing, but considering the financing constraints, it appears that this feature is provided by non financially constrained innovative companies. This is possible as, on the one hand, their solid financial structure allows them to contend with uncertainties relating to innovative investment, and on the other hand, this structure sends positive signals to financial partners, thus reducing the asymmetry of information, and enabling these firms to obtain better credit conditions.

Financial constraints on innovation projects result both from a sub-standard balance sheet structure and from investment-related risk.

\section{DO COMPANIES IN THE INFORMATION AND COMMUNICATION TECHNOLOGIES INDUSTRIES HAVE TO CONTEND WITH SPECIFIC FINANCING PROBLEMS?}

Despite the fact that, during the observed period, companies in the ICT industries appear less at risk than those in other industries, in that their failure rate ${ }^{27}$ is significantly lower (1.4\% compared with 4.6\%), the calculated interest rates applicable to ICT firms are almost identical (see Table 10). Indeed, the difference is never more than 4 basis points over the survey period.

\footnotetext{
${ }^{27}$ The failure rate: the number of failed companies over the period 1997-2000 divided by the number of companies monitored.
} 
Table 10: CALCULATED INTEREST RATES DURING THE PERIOD 1994-1996, APPLIED TO FIRMS IN/OUTSIDE THE ICT INDUSTRIES

\begin{tabular}{|l|cc|}
\hline & \multicolumn{2}{|c|}{$\begin{array}{ll}\text { Outside } \\
\text { ICT }\end{array}$} \\
\hline $\begin{array}{l}\text { Calculated interest rate on outside-group financial } \\
\text { debt, excluding guaranteed obligations }\end{array}$ & 11.2 & 11.4 \\
Calculated interest rate on intra-group financing & 3.3 & 2.9 \\
\hline Calculated interest rate on external financing & 8.4 & 8.5 \\
\hline
\end{tabular}

Sources: CIS 97, CBSO and authors' calculations

However, more than $25 \%$ of the firms in the ICT industries, and almost one-third of innovative companies ${ }^{28}$ claim to have been subject to financial constraints (See Appendix 7). The interest rate differentials between innovative and non-innovative firms, with or without financial constraints, previously observed for the total population, are the same for ICT firms (see Table 11).

Table 11: CALCULATED INTEREST RATES DURING THE PERIOD 1994-1996, FOR INNOVATIVE AND NON-INNOVATIVE ICT FIRMS STATING THAT THEY HAVE, OR HAVE NOT, BEEN SUBJECT TO FINANCIAL CONSTRAINTS

\begin{tabular}{|c|c|c|c|c|}
\hline & \multicolumn{2}{|c|}{ Non-innovative } & \multicolumn{2}{|c|}{ Innovative } \\
\hline & $\begin{array}{l}\text { Without } \\
\text { constraints }\end{array}$ & $\begin{array}{c}\text { With } \\
\text { constraints }\end{array}$ & $\begin{array}{l}\text { Without } \\
\text { constraints }\end{array}$ & $\begin{array}{c}\text { With } \\
\text { constraints }\end{array}$ \\
\hline $\begin{array}{l}\text { Calculated interest rate on outside-group financial } \\
\text { debt, excluding guaranteed obligations }\end{array}$ & 12.3 & 11.1 & 9.8 & 12.4 \\
\hline Calculated interest rate on intra-group financing & 2.1 & 1.7 & 2.4 & 2.5 \\
\hline Calculated interest rate on external financing & 9.5 & 8.4 & 8.1 & 8.4 \\
\hline
\end{tabular}

Sources: CIS 97, CBSO and authors' calculations

Innovative firms with financial constraints are subject to a higher outside-group calculated interest rate than innovative companies without constraints ${ }^{29}$. As mentioned above, this is in line with the financial structure of each of the two categories (see Table 12). The proportion of own financing of firms with financial constraints is far lower than that of firms without constraints $(55.4 \%$ versus $60.2 \%$ ). This difference is partially offset by the outside-group and inside-group financial debt, but above all by cyclic borrowings ( $25.8 \%$ versus $21.1 \%)$. Remember that recourse to cyclic borrowings is often a sign of financial difficulties.

Furthermore, other indicators confirm that, in the case of innovative firms, companies with financial constraints are weaker: their profit margin is significantly lower than that of innovative firms without financial constraints $(6.1 \%$ versus $9.2 \%)$ and their invested capital coverage ${ }^{30}$ is also lower $(0.9 \%$ versus $1.2 \%)$. Typically, the investment effort of innovative companies with constraints is much

\footnotetext{
${ }^{28}$ Innovative firms represented $64.4 \%$ of firms in the ICT industries and $84.6 \%$ in terms of turnover.

${ }^{29}$ The calculated interest rate on external financing is not different due to a balance sheet structure effect: intra-group loans comprise a larger proportion of the debt incurred by companies with financial constraints than by those without financial constraints.

${ }^{30}$ Stable financing/invested capital
} 
more substantial (25.2\% versus $15.7 \%)$. Furthermore, intangible assets account for almost one quarter of their investment $(21.7 \%$ versus $11.1 \%)$. This increases the credit-related risk in that, in the event of bankruptcy, intangible investments cannot be recovered by lenders.

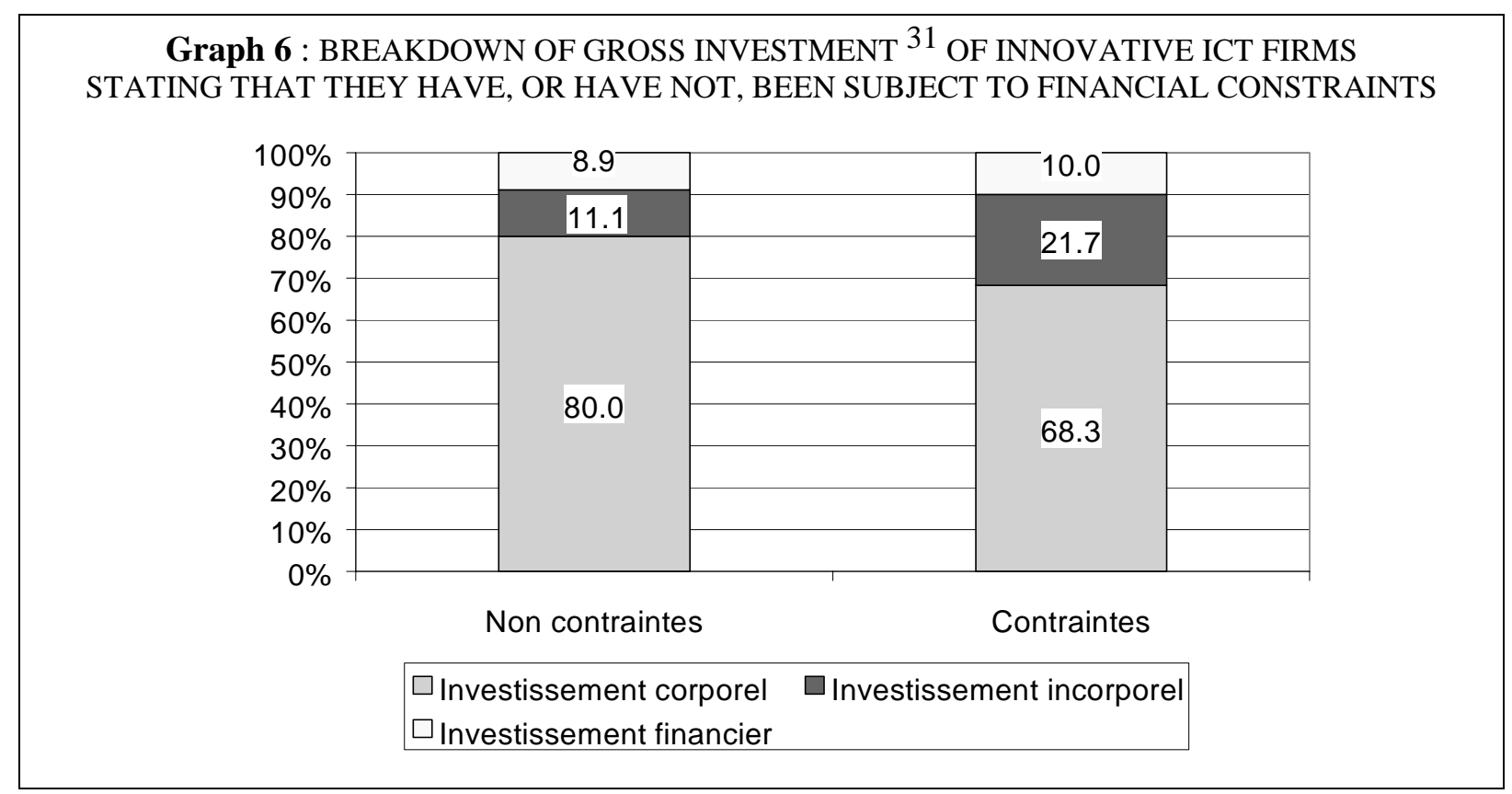

Sources: CIS 97, CBSO and authors' calculations

Among the firms without financial constraints, innovative companies enjoy a lower outsidegroup interest rate. Once again, this is due to the fact that the balance sheet structure of non-innovative firms is less favourable (see Tables 12 and 13). Unlike in other industries, the balance sheet structure of non-innovative ICT firms without constraints is closer to that of innovative firms with constraints than to that of companies without constraints. The proportion of own financing among non-innovative ICT firms without constraints is around 55\%, cyclic borrowings represent almost one quarter of the total balance sheet and their proportion of bank loans is even greater than that of innovative companies with financial constraints (13.5\% versus $10.4 \%$ in the survey period).

Furthermore, the financial structure of non-innovative firms with financial constraints, i.e. those which have attempted but failed to implement an innovation project, is more solid during the survey period than that of non-innovative firms without financial constraints. Non-innovative firms with financial constraints enjoy a lower outside-group calculated interest rate (11.1\% versus $12.3 \%)$. Admittedly, they have a higher outside-group financial debt, but this is due to the higher proportion of long-term bank loans and loans from other financial institutions. They have a smaller proportion of short-term debt (short-term bank loans + cyclic borrowings).

By comparing non-innovative companies with financial constraints to innovative companies with financial constraints during the period prior to the survey, it emerges that: for the former, the proportion of own financing was greater (58.2\% versus 55.4\%; see tables 12 and 13 ); financial debt was proportionally higher $(16.4 \%$ versus $12.6 \%)$ mainly due to bank borrowings $(14.8 \%$ versus $10.4 \%)$. Firms with financial constraints that managed to implement an innovation project benefited from substantial group financing $(5.8 \%$ versus $4.6 \%)$. However, they don't enjoyed a more favourable interest rate on external financing.

\footnotetext{
${ }^{31}$ Excluding charges to be spread over several periods
} 
Table 12 : BALANCE SHEET STRUCTURE OF INNOVATIVE ICT FIRMS WITH AND WITHOUT FINANCIAL CONSTRAINTS (controlled by size, industry and investment ratio)

\begin{tabular}{|c|c|c|c|c|}
\hline & $\begin{array}{l}\text { 1992-1993 } \\
\text { Without } \\
\text { constraints }\end{array}$ & With constraints & $\begin{array}{l}\text { 1994-1996 } \\
\text { Without } \\
\text { constraints }\end{array}$ & $\begin{array}{l}\text { With } \\
\text { constraints }\end{array}$ \\
\hline Own financing & 57.9 & 55.0 & 60.2 & 55.4 \\
\hline Investment subsidies & 0.1 & 0.0 & 0.0 & 0.0 \\
\hline Outside-group financial debt & 14.7 & 12.9 & 13.6 & 12.6 \\
\hline Market financing & 0.1 & 0.3 & 0.0 & 0.2 \\
\hline Bank borrowings & 12.8 & 10.4 & 12.1 & 10.4 \\
\hline long-term bank loans & 7.7 & 6.0 & 7.3 & 5.8 \\
\hline short-term bank loans & 5 & 4.4 & 4.9 & 4.6 \\
\hline Other financial debt & 1.9 & 2.1 & 1.5 & 2.0 \\
\hline Group financing & 6.1 & 7.4 & 7.3 & 5.8 \\
\hline Cyclic borrowings & 21.2 & 24.8 & 21.1 & 25.8 \\
\hline Total & 100.0 & 100.0 & 100.0 & 100.0 \\
\hline
\end{tabular}

Sources: CIS 97, CBSO and authors' calculations

Table 13 : BALANCE SHEET STRUCTURE OF NON-INNOVATIVE ICT FIRMS WITH AND WITHOUT FINANCIAL CONSTRAINTS (Controlled by size, industry and investment ratio)

\begin{tabular}{|c|c|c|c|c|}
\hline & \multicolumn{2}{|c|}{$1992-1993$} & \multicolumn{2}{|c|}{ 1994-1996 } \\
\hline & $\begin{array}{c}\text { Without } \\
\text { constraints }\end{array}$ & constraints & $\begin{array}{c}\text { Without } \\
\text { constraints }\end{array}$ & constraints \\
\hline Own financing & 54.1 & 55.5 & 55.6 & 58.2 \\
\hline Investment subsidies & 0.0 & 0.0 & 0.0 & 0.0 \\
\hline Outside-group financial debt & 16.4 & 18.9 & 14.2 & 16.4 \\
\hline Market financing & 0.1 & 0.0 & 0.0 & 0.0 \\
\hline Bank borrowings & 15.4 & 18.1 & 13.5 & 14.8 \\
\hline long-term bank loans & 7.5 & 10.9 & 6.9 & 8.0 \\
\hline short-term bank loans & 7.8 & 7.1 & 6.6 & 6.9 \\
\hline Other financial debt & 1.0 & 0.9 & 0.7 & 1.7 \\
\hline Group financing & 5.0 & 3.4 & 5.5 & 4.6 \\
\hline Cyclic borrowings & 24.4 & 22.2 & 24.6 & 20.7 \\
\hline Total & 100.0 & 100.0 & 100.0 & 100.0 \\
\hline
\end{tabular}

Sources: CIS 97, CBSO and authors' calculations

In view of the specific nature of the ICT industries in terms of technological advances (firms in these industries are obliged to constantly innovate in order to remain in business), it is likely that non- 
innovative companies without financial constraints (i.e. firms that have not even attempted to innovate) may be excluded from this market as they do not have a sufficiently solid financial structure (low proportion of own financing and high proportion of bank loans in particular during the period prior to the survey). Among the firms that experienced financial constraints, the difference between those that innovated and those that failed to do so, appears to be partly linked to access to group financing. Lastly, firms which innovated without financial constraints ( $43.1 \%$ of all ICT firms) managed to do so because their financial structure was sufficiently solid for them to bear the risk relating to returns on innovative investment. This gave them easier access to credit at more favourable rates.

\section{CONCLUSION}

In this empirical study, we have identified the specific features of innovative companies in terms of financing, access to credit, and risk for the economy as a whole, and also more specifically for the ICT sector.

Comparisons between innovative and non-innovative companies, taking into account the composition effect of size and industry, show that innovative firms are not riskier (in terms of failure risk) than non-innovative ones. Confirming the Williamson theory, they have a slightly better profile in terms of balance-sheet liabilities, in that the proportion of own financing in the balance sheet total is higher for innovative firms than non-innovative ones. Consequently, innovative companies enjoy more favourable financing conditions in terms of interest rates on external financing. At the macroeconomic level, it appears that, compared to their contribution to total turnover, innovative companies absorb a greater proportion of own financing, group financing and market financing than non-innovative companies. Conversely, they use a smaller proportion of bank borrowing and other financial debt.

A closer comparison between innovative and non-innovative firms reveals that the presence of financing constraints is a determining criterion in the analysis for both categories of firm.

Data from SESSI show which firms have experienced financing constraints for to their innovative projects. We can distinguish four categories of firm: those which have not attempted to innovate (or ended their innovation projects for other reasons than financing constraints), those which aborted their innovation projects as a result of financing constraints, those which innovated despite the presence of financing constraints, and those innovative firms which did not experience financing constraints.

More than one-third of companies with an innovation project claim that they experienced financing constraints, and $16.4 \%$ of those firms wishing to innovate had to abandon their projects because of these difficulties (at least partially).

The comparison of cost of credit and financial structures for the four categories, throws light on the differences observed between innovative and non-innovative firms. First, the presence of financial constraints results in a significantly higher cost of credit for innovative firms, whether the latter relates to intra-group or outside-group debts. Second, in the survey period (1994-96), the proportion of own financing in the balance sheet total of companies that have experienced financial constraints (whether they have innovated or not) is markedly lower than that of innovative firms that have not experienced constraints $(51.7 \%$ and $50.9 \%$ respectively versus $56.2 \%)$. Innovative firms, not having experienced constraints, were those with the most solid financing structures and the most advantageous cost of credit. The financial structure of companies that abandon their innovation projects does not allow them to contend with uncertainties relating to innovative investment. Consequently, this structure sends negative signals to financial partners, who tighten up credit conditions. Furthermore, firms that have not attempted to innovate display an "average" balance sheet structure and performance, half-way between those of innovative companies with and without financial constraints. 
The observations made about the economy as a whole are particularly apparent in the ICT sector, with, however, one difference. In the ICT sector, the situation of firms that have not attempted to innovate (non-innovating, without financial constraints) is worse than firms that abandoned an innovative project as a result of financial constraints. This is probably due to the fact that ICT firms need to make technological advances and innovate. Those that do not will very likely be excluded from this market due to their financial structure. This is not the case across all industries of the economy, where non-innovative companies are able to choose whether to innovate or not. Moreover, the proportion of group financing in the balance sheet total is higher for innovative but financially constrained companies from the ICT sector than for companies which abandoned their innovative project as a result of financial constraints.

In conclusion, the asymmetry of information associated with an innovation project means that companies need to finance these projects using a high proportion of own financing, thus limiting such undertakings to companies with a better-than-average financial position. Consequently, these firms can obtain loans at lower rates than those offered to companies with a weaker financial position. 


\section{BIBLIOGRAPHY}

Biais B., P. Hillion and J.-F. Malécot (1995), «La structure financière des entreprises: une investigation empirique sur données françaises », Economie et Prévision, n¹20, pp.15-28.

Chabbal R. (1995), Le système financier français face à l'investissement innovation, Rapport du ministère des entreprises et du développement économique, La Documentation française.

Conseil National du Crédit et du Titre (1999), Le financement de l'entreprise, Rapport.

Crépon B. and N. Iung (1999), «Innovation, emploi et performances », INSEE, document de travail G 9904.

Crépon B. and F. Rosenwald (2000), «Investissement et contraintes de financement : le poids du cycle » INSEE, document de travail G 2000/05.

Dietsch M., N. Eber and B. Godbillion-Camus (2000), Financement de l'innovation et performance des entreprises, Rapport pour le SESSI.

Duguet E. and S. Monjon (2001), Creative Destruction and the Innovative Core : Is innovation Persistent at the Firm Level? (Mimeo)

Guillaume H. (1998), «Rapport sur la technologie de l'innovation », Ministère de l'Économie, des Finances et de l'Industrie.

Sauvé A. (1999), «Le financement de l'innovation », Bulletin de la Banque de France n65 (mai).

Scholtens B. et D. Van Wensveen (2000), «A critique on the theory of financial intermediation », Journal of Banking and Finance, 24, pp.1243-1251.

SESSI (1996), L'innovation technologique dans l'industrie, Ministère de l'Économie, des Finances et de l'Industrie - Secrétariat d'état à l'Industrie.

Williamson O.E. (1988), «Corporate Finance and Corporate Governance », The Journal of Finance, n²3.3, pp. 567-91. 


\section{PRESENTATION OF THE DATABASES}

\section{Community study on innovation 1994-1996. (CIS 2)}

For industry, a representative sample of 5,000 industrial companies (excluding agri-food and energy) were surveyed. The response rate was $85 \%$ in terms of number of units, and over $95 \%$ in terms of turnover.

For services, the industries surveyed were "Transport, storage and communication" and "Real estate, rental and business services".

In both studies, only firms with over 20 employees were surveyed.

Companies were surveyed about the type of innovations, how these innovations were managed, innovation expenditure, turnover from innovative products, internal and external sources of innovation, co-operation in innovation projects, the objectives of and obstacles to the innovation project.

\section{The Central Balance Sheet Offices of the Banque de France 1992-1999.}

In addition to the standard income statements, this database supplies the additional financial and accounting statements necessary to provide a complete definition of the investment and debt variables.

By combining this database to the community survey a coverage ratio of $50 \%$ can be obtained. The breakdown by NACE industry and by company size is given in the Appendix.

\section{The Banque de France database on legal incidents 1994 - 1999}

This database contains information on failures of companies in the Central Balance Sheet Offices database.

\section{Breakdown:}

We carried out a breakdown by size (between 20 and 49 employees, between 50 and 99 , between 100 and 499 over 500) and by industry (NES 114) based on all companies in the INSEE database with over 20 employees and which are subject to the specific French BIC-BRN tax regime.

\section{Definition of innovative firms:}

All companies which have replied affirmatively to at least one of the following questions are deemed "innovative":

1. Between 1994 and 1996, did your company market any technologically innovative (or improved) products, which were developed either by your company with other companies or organisations, or mainly by your company?

2. Between 1994 and 1996, did your company market any technologically innovative or improved processes, which were developed either by your company with other companies or organisations, or mainly by your company?

3. Between 1994 and 1996, did your company have any projects for new or improved products or processes still being developed or marketed or which failed?

The definition of innovation that we have used is narrower that that used by SESSI: we do not consider firms that marketed an innovation mainly developed by other companies or organisations as being innovative. 


\section{Coverage ratio to number of companies in the CIS 97 database by the Banque de France Central Balance Sheet Offices}

\begin{tabular}{|c|c|c|c|c|c|c|c|}
\hline NACE classification & Data & 20 to 49 & 50 to 99 & $\begin{array}{c}100 \text { to } \\
199\end{array}$ & $\begin{array}{c}200 \text { to } \\
499\end{array}$ & $500+$ & Total \\
\hline \multirow{3}{*}{$\begin{array}{l}\text { CB Mining and quarrying except energy } \\
\text { producing materials }\end{array}$} & CIS 97 & 31 & 12 & 6 & 7 & 5 & 61 \\
\hline & $\mathrm{CBSO}$ & 13 & 7 & 2 & 5 & 3 & 30 \\
\hline & coverage & 41.9 & 58.3 & 33.3 & 71.4 & 60.0 & 49.2 \\
\hline \multirow{3}{*}{$\begin{array}{l}\text { DB Manufacture of textiles and textile } \\
\text { products }\end{array}$} & CIS 97 & 268 & 101 & 75 & 62 & 31 & 537 \\
\hline & CBSO & 103 & 64 & 56 & 52 & 27 & 302 \\
\hline & coverage & 38.4 & 63.4 & 74.7 & 83.9 & 87.1 & 56.2 \\
\hline \multirow{3}{*}{$\begin{array}{l}\text { DC Manufacture of leather and leather } \\
\text { products }\end{array}$} & CIS 97 & 34 & 16 & 17 & 22 & 10 & 99 \\
\hline & CBSO & 13 & 10 & 12 & 18 & 9 & 62 \\
\hline & coverage & 38.2 & 62.5 & 70.6 & 81.8 & 90.0 & 62.6 \\
\hline \multirow{3}{*}{$\begin{array}{l}\text { DD Manufacture of wood and wood } \\
\text { products }\end{array}$} & CIS 97 & 46 & 29 & 10 & 10 & 4 & 99 \\
\hline & CBSO & 23 & 26 & 9 & 6 & 2 & 66 \\
\hline & coverage & 50.0 & 89.7 & 90.0 & 60.0 & 50.0 & 66.7 \\
\hline \multirow{3}{*}{$\begin{array}{l}\text { DE Manufacture of pulp, paper and paper } \\
\text { products, publishing and printing }\end{array}$} & CIS 97 & 177 & 96 & 45 & 82 & 68 & 468 \\
\hline & CBSO & 88 & 65 & 28 & 60 & 55 & 296 \\
\hline & coverage & 49.7 & 67.7 & 62.2 & 73.2 & 80.9 & 63.2 \\
\hline \multirow{3}{*}{ DG Chemicals industry } & CIS 97 & 64 & 51 & 37 & 79 & 114 & 345 \\
\hline & $\mathrm{CBSO}$ & 27 & 34 & 23 & 56 & 96 & 236 \\
\hline & coverage & 42.2 & 66.7 & 62.2 & 70.9 & 84.2 & 68.4 \\
\hline \multirow{3}{*}{ DH Manufacture of rubber and plastics } & CIS 97 & 85 & 50 & 41 & 36 & 49 & 261 \\
\hline & CBSO & 51 & 28 & 30 & 29 & 38 & 176 \\
\hline & coverage & 60.0 & 56.0 & 73.2 & 80.6 & 77.6 & 67.4 \\
\hline \multirow{3}{*}{$\begin{array}{l}\text { DI Manufacture of other non-metallic } \\
\text { mineral products }\end{array}$} & CIS 97 & 69 & 40 & 21 & 29 & 45 & 204 \\
\hline & CBSO & 45 & 30 & 16 & 22 & 42 & 155 \\
\hline & coverage & 65.2 & 75.0 & 76.2 & 75.9 & 93.3 & 76.0 \\
\hline \multirow{3}{*}{$\begin{array}{l}\text { DJ Manufacture of basic metals and } \\
\text { fabricated metal products }\end{array}$} & CIS 97 & 376 & 160 & 83 & 95 & 97 & 811 \\
\hline & CBSO & 196 & 113 & 66 & 84 & 88 & 547 \\
\hline & coverage & 52.1 & 70.6 & 79.5 & 88.4 & 90.7 & 67.4 \\
\hline \multirow{3}{*}{$\begin{array}{l}\text { DK Manufacture of machinery and } \\
\text { equipment }\end{array}$} & CIS 97 & 151 & 90 & 68 & 66 & 78 & 453 \\
\hline & CBSO & 87 & 68 & 57 & 55 & 70 & 337 \\
\hline & coverage & 57.6 & 75.6 & 83.8 & 83.3 & 89.7 & 74.4 \\
\hline \multirow{3}{*}{$\begin{array}{l}\text { DL Manufacture of electrical and } \\
\text { electronic equipment }\end{array}$} & CIS 97 & 127 & 97 & 53 & 87 & 137 & 501 \\
\hline & CBSO & 60 & 66 & 31 & 64 & 110 & 331 \\
\hline & coverage & 47.2 & 68.0 & 58.5 & 73.6 & 80.3 & 66.1 \\
\hline \multirow{3}{*}{ DM Manufacture of transport equipment } & CIS 97 & 53 & 21 & 20 & 37 & 93 & 224 \\
\hline & CBSO & 21 & 12 & 16 & 32 & 82 & 163 \\
\hline & coverage & 39.6 & 57.1 & 80.0 & 86.5 & 88.2 & 72.8 \\
\hline \multirow{3}{*}{ DN Other manufacturing industries } & CIS 97 & 78 & 41 & 27 & 33 & 31 & 210 \\
\hline & CBSO & 37 & 28 & 21 & 26 & 28 & 140 \\
\hline & coverage & 47.4 & 68.3 & 77.8 & 78.8 & 90.3 & 66.7 \\
\hline \multirow{3}{*}{ II Transport, storage and communication } & CIS 97 & 823 & 178 & 180 & 124 & 46 & 1351 \\
\hline & $\mathrm{CBSO}$ & 126 & 76 & 98 & 49 & 19 & 368 \\
\hline & coverage & 15.3 & 42.7 & 54.4 & 39.5 & 41.3 & 27.2 \\
\hline \multirow{3}{*}{$\begin{array}{l}\text { KK Real estate, renting and business } \\
\text { activities }\end{array}$} & CIS 97 & 727 & 157 & 186 & 105 & 48 & 1223 \\
\hline & CBSO & 93 & 35 & 63 & 34 & 19 & 244 \\
\hline & coverage & 12.8 & 22.3 & 33.9 & 32.4 & 39.6 & 20.0 \\
\hline \multirow{3}{*}{ As a whole } & CIS 97 & 3109 & 1139 & 869 & 874 & 856 & 6847 \\
\hline & CBSO & 983 & 662 & 528 & 592 & 688 & 3453 \\
\hline & coverage & 31.6 & 58.1 & 60.8 & 67.7 & 80.4 & 50.4 \\
\hline
\end{tabular}

$\mathrm{CBSO}=$ Central Balance Sheet Offices 


\section{Definition of the ICT industries and CBSO coverage ratio}

ICT industries are those selected by the French Economic Information and Forecast Office (BIPE) ${ }^{32}$. Two ICT industries were not included in the innovation survey:

51.5: Wholesale industrial equipment

71.33: Rental of office and computer equipment

Therefore, the following are considered to be part of the ICT industries:

3001 Manufacture of office equipment

3002 Manufacture of computers and other IT equipment

3130 Manufacture of insulated cables and wires

3210 Manufacture of electronic components

3220 Manufacture of transmission and broadcasting devices

3230 Manufacture of sound and image reception, recording and reproduction devices

3320 Manufacture of measuring and monitoring instruments

3330 Manufacture of industrial process monitoring equipment

6420 Telecommunications

7210 IT systems consultancy

7220 Software development

7230 Data processing

7240 Database activities

7250 Maintenance and repairs of office and IT equipment

ICT coverage ratio

\begin{tabular}{|l|r|r|r|r|r|c|}
\hline Data & 20 to 49 & 50 to 99 & 100 to 199 & 200 to 499 & $500+$ & Total \\
\hline CIS 97 & 454 & 153 & 143 & 118 & 107 & 975 \\
CBSO & 80 & 55 & 54 & 56 & 64 & 309 \\
Coverage & 17.6 & 35.9 & 37.8 & $\mathbf{4 7 . 5}$ & $\mathbf{5 9 . 8}$ & \multicolumn{3}{|c|}{31.7} \\
\hline
\end{tabular}

\footnotetext{
${ }^{32}$ BIPE report: "Les technologies de l'information et des communications et l'emploi en France”, Ministry of the Economy, Finance and Industry, June 2000.
} 


\section{Cost of credit}

(as \%)

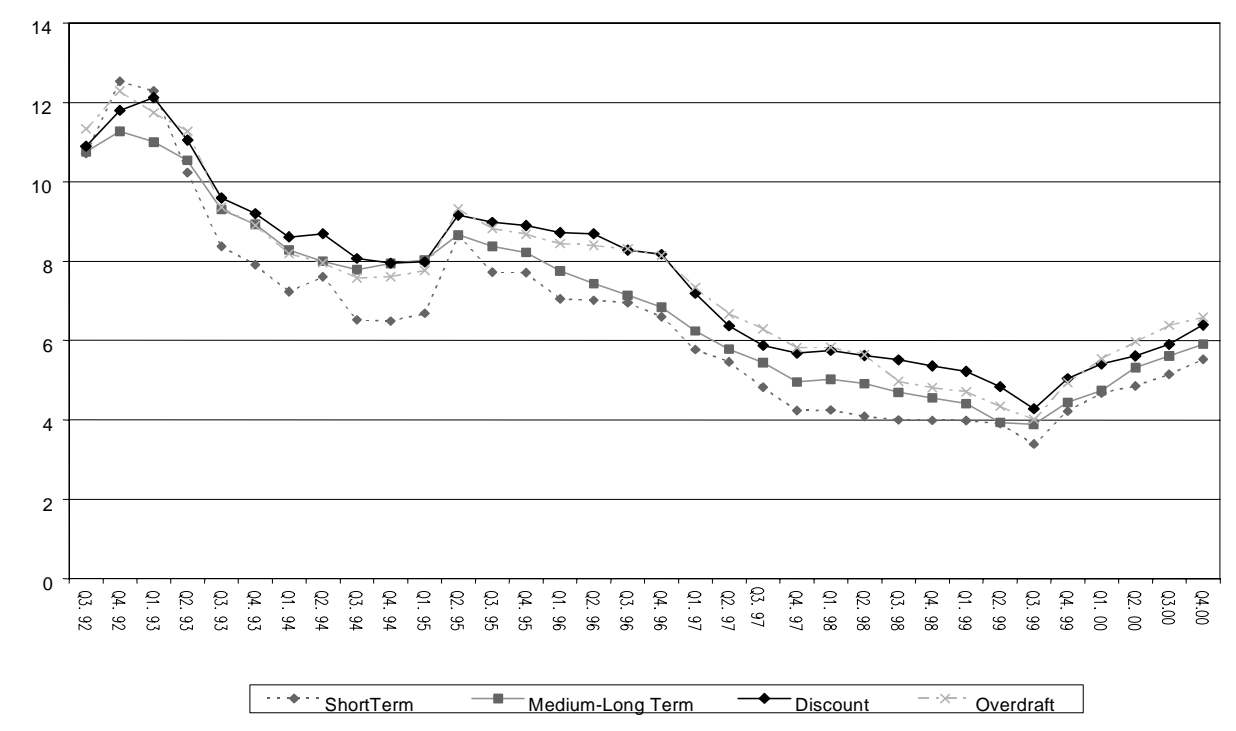

Source: Business Conditions Directorate-Banque de France 


\section{Calculation of average ratios for a given size, industry and investment level}

We calculated the average financing ratios for a given size and industry was made using the GLM procedure of the SAS software. This formula makes it possible to carry out the regression of a variable on different classification variables, in this case the category, size and industry. Where, Zijkl is the ratio of company $i$, with category $j$, belonging to industry $l$ and of size $k$, the regression is expressed as follows:

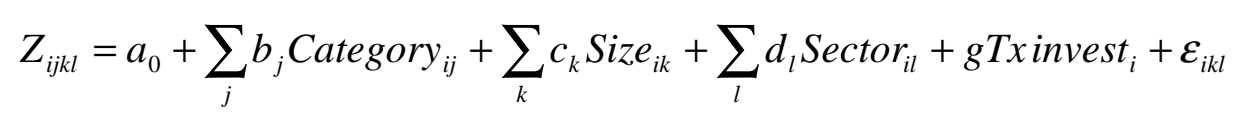

where

Category $_{i j}$ is an indicative variable with a value of 1 if company $i$ is in category $j$ (innovative/non-innovative), otherwise its value is 0

$S_{i z e_{i k}}$ is an indicative variable with a value of 1 if company $i$ is of size $k$, otherwise its value is 0

Sector $_{i l}$ is an indicator variable with a value of 1 if company $i$ belongs to industry $l$, otherwise its value is 0

Txinvest $_{i}$ is the investment ratio of company $i$.

Where $N$ is the total number of companies, $N_{\text {Size }}$ the number of companies of size $k$ and $N$ Sector $_{l}$ the number of companies in industry $l$, the average of ratio $Z$ for the companies in category $j$, for a given size, industry and investment ratio, is expressed as follows:

$$
Z_{j \bullet \bullet}=\hat{a}_{0}+\hat{b}_{j}+\frac{1}{N} \sum_{k} \hat{c_{k}} \text { NSize }_{k}+\frac{1}{N} \sum_{l} \hat{d}_{l} \text { NSector }_{l}+\hat{g} \frac{1}{N} \sum \text { TxInvest }
$$




\section{Percentage of companies claiming to have been subject to financial constraints, by industry}

Controlling for size and industry

\begin{tabular}{|l|c|c|c|}
\hline & $\begin{array}{c}\text { non- } \\
\text { innovative }\end{array}$ & Innovative & Overall \\
\hline Mining and quarrying except energy producing materials & 0.0 & 11.1 & 2.7 \\
Manufacture of textiles and textile products & 15.0 & 19.2 & 17.1 \\
Manufacture of leather and leather products & 13.5 & 19.6 & 16.0 \\
Manufacture of wood and wood products & 15.3 & 10.2 & 13.7 \\
Manufacture of pulp, paper and paper products, publishing & 17.1 & 26.2 & 21.0 \\
and printing & 7.4 & 17.1 & 14.3 \\
Chemicals industry & 15.0 & 18.0 & 17.1 \\
Manufacture of rubber and plastics & 15.8 & 21.5 & 19.4 \\
Manufacture of other non-metallic mineral products & 16.5 & 22.8 & 20.2 \\
Manufacture of basic metals and fabricated metal products & 19.3 & 22.9 & 22.1 \\
Manufacture of machinery and equipment & 13.7 & 33.2 & 28.6 \\
Manufacture of electrical and electronic equipment & 25.8 & 37.4 & 34.1 \\
Manufacture of transport equipment & 18.4 & 16.1 & 17.3 \\
Other manufacturing industries & 24.9 & 24.6 & 25.5 \\
Transport, storage and communication & 23.7 & 29.2 & 27.7 \\
\hline Real estate, renting and business activities & & &
\end{tabular}




\section{Percentage of companies \\ making use of different types of financing \\ by size and category}

Period 1992-1993

\begin{tabular}{|c|c|c|c|c|c|c|}
\hline & \multicolumn{3}{|c|}{ Non-innovative } & \multicolumn{3}{|c|}{ Innovative } \\
\hline & $\begin{aligned} & \text { Turn. } \\
&<\text { FRF 50M } \\
&\end{aligned}$ & $\begin{array}{c}\text { Size } \\
\text { FRF 50M } \\
<\text { Turn. < } \\
\text { FRF 250M } \\
\end{array}$ & $\begin{array}{c}\text { Turn. } \\
\text { > FRF 250M } \\
\end{array}$ & $\begin{array}{c}\text { Turn. } \\
<\text { FRF 50M } \\
\end{array}$ & $\begin{array}{c}\text { Size } \\
\text { FRF 50M } \\
<\text { Turn. < } \\
\text { FRF 250M } \\
\end{array}$ & $\begin{array}{c}\text { Turn. } \\
\text { > FRF } 250 \mathrm{M} \\
\end{array}$ \\
\hline Market & 1.9 & 5.2 & 9.2 & 2.8 & 6.2 & 11.0 \\
\hline Other financial debt & 38.3 & 56.9 & 71.0 & 47.9 & 65.9 & 77.1 \\
\hline Bank borrowings & 96.7 & 98.3 & 100.0 & 98.8 & 97.1 & 99.1 \\
\hline L-M-term bank loans & 91.6 & 90.7 & 88.0 & 92.2 & 87.5 & 80.1 \\
\hline S-term bank loans & 82.9 & 89.8 & 98.9 & 88.7 & 92.3 & 97.0 \\
\hline Group borrowings & 84.9 & 89.8 & 97.2 & 85.8 & 90.0 & 97.7 \\
\hline
\end{tabular}

Period 1994-96

\begin{tabular}{|c|c|c|c|c|c|c|}
\hline & \multicolumn{3}{|c|}{ Non-innovative } & \multicolumn{3}{|c|}{ Innovative } \\
\hline & $\begin{array}{c}\text { Turn. } \\
\text { < FRF 50M } \\
\end{array}$ & $\begin{array}{c}\text { Size } \\
\text { FRF 50M } \\
<\text { Turn. }< \\
\text { FRF 250M } \\
\end{array}$ & $\begin{array}{c}\text { Turn. } \\
\text { > FRF 250M } \\
\end{array}$ & $\begin{array}{c}\text { Turn. } \\
<\text { FRF 50M } \\
\end{array}$ & $\begin{array}{c}\text { Size } \\
\text { FRF 50M } \\
<\text { Turn. < } \\
\text { FRF 250M } \\
\end{array}$ & $\begin{array}{c}\text { Turn. } \\
\text { > FRF } 250 \mathrm{M} \\
\end{array}$ \\
\hline Market & 1.9 & 5.2 & 9.2 & 2.8 & 6.2 & 11.0 \\
\hline Bank borrowings & 96.7 & 98.3 & 100.0 & 98.8 & 97.1 & 99.1 \\
\hline L-M-term bank loans & 91.6 & 90.7 & 88.0 & 92.2 & 87.5 & 80.1 \\
\hline S-term bank loans & 82.9 & 89.8 & 98.9 & 88.7 & 92.3 & 97.0 \\
\hline Other financial debt & 38.3 & 56.9 & 71.0 & 47.9 & 65.9 & 77.1 \\
\hline Group borrowings & 84.9 & 89.8 & 97.2 & 85.8 & 90.0 & 97.7 \\
\hline
\end{tabular}

Sources: CIS 97, CBSO and authors' calculations 


\title{
Calculated interest rates for loans granted to innovative and non-innovative firms during the survey period
}

\author{
By degree of innovation of industry
}

\begin{tabular}{|c|c|c|c|c|c|c|}
\hline & \multicolumn{2}{|c|}{ Low } & \multicolumn{2}{|c|}{ Average } & \multicolumn{2}{|c|}{ High } \\
\hline & $\begin{array}{l}\text { Non } \\
\text { inno. }\end{array}$ & Inno. & $\begin{array}{l}\text { Non } \\
\text { inno. }\end{array}$ & Inno. & $\begin{array}{l}\text { Non } \\
\text { inno. }\end{array}$ & Inno. \\
\hline $\begin{array}{l}\text { Calculated interest rate on outside-group } \\
\text { financial debt, excluding guaranteed } \\
\text { obligations }\end{array}$ & 11.1 & 10.7 & 12.0 & 10.4 & 12.2 & 11.4 \\
\hline $\begin{array}{l}\text { Calculated interest rate on intra-group } \\
\text { financing }\end{array}$ & 3.2 & 3.2 & 2.9 & 3.3 & 4.5 & 3.2 \\
\hline $\begin{array}{l}\text { Calculated interest rates on external } \\
\text { financing }\end{array}$ & 10.5 & 10.1 & 10.6 & 9.3 & 10.8 & 9.8 \\
\hline
\end{tabular}

Sources: CIS 97, CBSO and authors' calculations

The classification by degree of innovation is determined by the proportion of innovative firms' turnover in total industrial turnover:

Low: "Mining and quarrying except energy producing materials", "Transport, storage and communication ", "Manufacture of leather and leather products", "Manufacture of textiles and textile products", "Manufacture of pulp, paper and paper products, publishing and printing" and "Manufacture of wood and wood products".

Average: "Other manufacturing industries", "Real estate, renting and business activities", "Manufacture of basic metals and fabricated metal products", "Manufacture of rubber and plastics" and "Manufacture of other non-metallic mineral products".

High: "Chemicals industry", "Manufacture of machinery and equipment", "Manufacture of electrical and electronic equipment" and "Manufacture of transport equipment". 


\section{Percentage of firms in ICT industries}

with a delayed, unstarted or abandoned innovation project by type of obstacles encountered

(adjusted sample)

\begin{tabular}{|lcc|c|}
\hline \multicolumn{1}{|c|}{ Obstacles } & \multicolumn{2}{c|}{ ICT } & $\begin{array}{c}\text { All } \\
\text { industries } \\
\text { combined }\end{array}$ \\
\hline & Non-innovative & Innovative & Innovative \\
\hline Economic & $\mathbf{2 8 . 4}$ & $\mathbf{5 3 . 1}$ & $\mathbf{5 3 . 9}$ \\
$\quad$ Financial & 27.6 & 45.8 & 42.7 \\
Of which only lack of appropriate & 15.7 & 32.0 & 24.4 \\
Profitability sources of finance & 23.6 & 33.5 & 38.1 \\
Organisational & $\mathbf{3 1 . 2}$ & $\mathbf{4 6 . 7}$ & $\mathbf{4 4 . 7}$ \\
Legal & $\mathbf{1 4 . 7}$ & $\mathbf{1 6 . 9}$ & $\mathbf{1 6 . 6}$ \\
Market-related & $\mathbf{1 2 . 4}$ & $\mathbf{2 4 . 2}$ & $\mathbf{2 5 . 7}$ \\
\hline Total & $\mathbf{4 3 . 0}$ & $\mathbf{7 3 . 0}$ & $\mathbf{7 1 . 8}$ \\
\hline
\end{tabular}

Sources: CIS 97, CBSO and authors' calculations 